\title{
The Role of Religiosity in the Psychological Well-Being of Young Adulthood Women with Acne Problems
}

\author{
Jeaneta Monica Tentero ${ }^{1}$ Raja Oloan Tumanggor ${ }^{1 *}$ Willy Tasdin $^{1}$ \\ ${ }^{1}$ Faculty of Psychology, Tarumanagara University, West Jakarta 11440, Indonesia \\ "Corresponding author. Email: rajat@fpsi.untar.ac.id
}

\begin{abstract}
Acne is a skin disease that can be associated physical and psychological problems. Psychological problems result from feelings of social isolation, low self-esteem, social inavailability, and social withdrawal. Psychological well-being is a healthy, fully operational mental and mental health condition of the individual. Previous studies linked the relationship of religious and psychological well-being. Religiosity is the depth of religious thought and internalization in daily life. This study aimed to identify the role of religiosity in psychological well-being of early female females suffering from acne problems. This study used a quantitative method with a total of 306 women who were in an age range of 20 - 40 years and experienced acne problems. Participants were selected using nonprobability sampling with purposive sampling technique. Based on the results, researcher found that religiosity has a role in psychological well-being, with $\mathrm{R}^{2}=$ $0.139, p=0.0000<0.05$. This shows that religiosity has a role of $13.9 \%$ on psychological well-being, and $86.1 \%$ is influenced by other factors. The dimension of religiosity that played the most role on psychological well-being in this study was religious experience with a percentage of $13.4 \%$.
\end{abstract}

\section{Keywords: Religiosity, Psychological Well-Being, Acne-Vulgaris, Young Adulthood Woman}

\section{INTRODUCTION}

Zaenglein (2018) [1] describes acne as a common disorder that affects $85 \%$ of people aged 12 to 25 years in the United States. Acne disorders often continue into adulthood with a percentage of $26 \%$ for women and $12 \%$ for men. Acne is a problem for two million Indonesians that occur in adolescence and early adulthood (Kumampung, 2019) [2]. The factors that cause acne can be influenced by weather and hormonal changes (Kumampung, 2019).

According to Himalaya survey in ten major cities in Indonesia (in Mutiah, 2020) [3], 86\% of female respondents said that they experience acne problems every month and as many as $32 \%$ experience them every week. This survey data also states that $77 \%$ of female respondents admit that they have acne shaming. $38 \%$ of nonverbal acne shaming consisted of gazes, gestures and facial expressions of disgust from others. In fact, $20 \%$ of respondents said that they received the treatment of being talked about on their backs. The judgments and attitudes of the people around will influence individuals in seeing themselves. The face is generally the first thing person will notice and acne can negatively affect the perceptions of others (Zaenglein, 2018).

Hormonal and lifestyle changes in adolescents and early adulthood trigger acne (Alajlan, 2017) [4]. Acne in adulthood or post-adolescent acne associated with androgen hormones is most often seen in women (Kaur et al., 2016) [5]. Adults who experience acne report feelings of insecurity in their social life, relationships, and work. They often make important decisions in life based on how they feel about acne (Traube, 2017). According to Gao et al. (2017) [6] acne sufferers have a high risk of mental health.

Sarkar et al. (2016) [7] stated that personality disorders appeared in $29.2 \%$ of 65 female patients with acne. The most common personality disorders are obsessive compulsive personality disorder, anxiety (avoidance), personality disorder, and borderline personality disorder. Teens and adults who experience acne tend to feel worried, inferior, and depressed (Zaenglein, 2018). Research conducted by Gao et al. (2017) suggested that acne problems may be correlated to depression and suicidal thoughts among early adults. In the study of Bassi et al. (2017) [8] there is a significant negative relationship between the dimensions of psychological well-being and depression.

According to research by Pradhan and Xiong (2017) [9], the results of interviews with patients who experience acne problems stated that they had complaints. Some of these complaints include feeling sad, irritable, looking down on themselves, feeling compared to others and disrespectful, unstable interpersonal relationships, mental disorders, loss of appetite, insomnia, fear of receiving criticism, anxiety, depression and thoughts of suicide. Halvorsen (in Pradhan and Xiong, 2017), states that the suicidal ideation in female patients with acne is twofold. Acne patients have 
psychological and emotional stress that affects the quality of life (Luqman et al., 2019). Acne problems can occur at any age, but adults are vulnerable to emotional impact (Traube, 2017) [10].

According to research by Pradhan and Xiong (2017) [9], the results of interviews with patients who experience acne problems stated that they had complaints. Some of these complaints include feeling sad, irritable, looking down on themselves, feeling compared to others and disrespectful, unstable interpersonal relationships, mental disorders, loss of appetite, insomnia, fear of receiving criticism, anxiety, depression and thoughts of suicide. Halvorsen (in Pradhan and Xiong, 2017), states that the suicidal ideation in female patients with acne is twofold. Acne patients have psychological and emotional stress that affects the quality of life (Luqman et al., 2019). Acne problems can occur at any age, but adults are vulnerable to emotional impact (Traube, 2017) [10]

The nature of religiosity is related to longevity and physical and mental health (Zimmer et al., 2016) [13]. Religiosity means the importance of religion for someone (Huber, 2012) [14]. Dew et al. (2008) [15] stated that religiosity is strongly associated with mental health such as drug use, anxiety, suicide, and delinquency. Research by Kaliampos and Roussi (2015) [16] states that the understanding of religion has a positive effect on difficult conditions.

Hamidah and Gamal's research (2019) [17] shows that there is a positive relationship between religiosity and psychological well-being. This means that the higher the religiosity, the higher the psychological well-being. These results are in line with research by Linawati and Desiningrum (2018) [18], that there is a positive relationship between religiosity and psychological wellbeing. In this study, religiosity increased psychological well-being by a percentage of $57.2 \%$. Based on this study, it was explained that the ideological dimensions of religiosity were related to the dimensions of the life goal of psychological well-being.

Patrick and Kinney (in Davis \& Kiang, 2014) [19] found that the existence of a higher level of religiosity was directly related to both positive and negative impacts with depressive symptoms found in older and younger adult individuals. Gwin et al. (in Weber \& Pargament, 2014) [20] states that the level of religiosity in early adulthood is associated with higher levels of depression. A large amount of research has established a clear correlation between religion and psychological well-being, with religion having both positive and negative implications depending on how religion is used and understood.

\subsection{Paper Structure}

In general, this paper is divided into five interrelated parts. The first part contains an introduction consisting of background problems, problem formulations, research objectives, and the benefits of theoretical and practical research regarding the role of religiosity on psychological well-being in early adulthood women with acne problems.
The second part contains a theoretical review that explains various sources of theoretical references related to the formulation and problem limitations of the research conducted. The third part contains research methods which contain observational methods and research methods to be carried out by researchers and how to take samples. The fourth section contains research findings and data analysis. The fifth section contains conclusions, discussions and suggestions.

\section{THEORY}

\subsection{Psychological Well-Being}

\subsubsection{Definition of Psychological Well-Being}

According to Ryff (1989) [21], psychological well-being is a term used to describe an individual's mental health in accordance with the criteria for positive psychological functioning. The point of view of this positive psychology function uses Maslow's theory of self-actualization, Roger's theory of fully functioning individuals, Jung's formulation of individuation, and Allport's theory of the concept of maturity. The definition of psychological wellbeing from the perspective of life-span development refers to Erikson's psychosocial concept. This concept states that at each stage of development there are different challenges and individuals will tend to achieve life goals.

Psychological well-being has another meaning from one individual to another. Psychological well-being is a relative state of mind when a healthy person is able to cope with and adjust to the stresses that recur in everyday life (Wells, 2010) [22]. According to Maslow and Roger's theory (in Wells, 2010) the achievement of psychological well-being and individual fulfillment is the impact of selfactualization and the views of fully functioning individuals.

\subsubsection{Dimension of Psychological Well-Being}

Ryff (1989) explained that there are six dimensions to having good psychological swings. The first dimension is self-destructive. Individuals who have self-acceptance maintain a positive attitude in themselves; Can acknowledge and accept weaknesses and strengths; And be able to think positively of past lives. But instead, individuals who are unable to accept themselves will be less content with themselves; Disillusioned by the events of a past life; Had problems with certain personal qualities; and desire to become another person.

The second dimension is positive relations with others. The criteria of maturity are individuals capable of connecting with others. The theory of adult development also emphasizes the intimacy and ability to guide others. Individuals who have positive relationships with other individuals will have good, satisfying, and mutual trust; Concerned about the welfare of others; Empathy, affection, and intimacy; And be able to understand, give and accept relationships towards others. Whereas 
individuals who have less positive relationships with others will lack intimate and trustworthy relationships with other individuals; The difficulty of finding them is friendship, openness, and concern for others; Isolated and fructured in interpersonal relationships; and it's hard keeping relationships with other people.

The third dimension was autonomy. Independent individuals can break free from fear, confidence, and public rule. Self-sufficient individuals are able to fight social issues, be able to think and act in specific ways, control behavior from within, and evaluate themselves according to personal standards. Rather, individuals who are not independent will rely on the opinions of others in decision-making and following social issues in behavior and thought.

The fourth dimension is an environmental mastery. Individuals capable of controlling the environment will then have the ability to control the environment in external complex activities, use existing opportunities effectively, and be able to determine or create situations that suit individual needs and worth. While individuals who are unable to master the environment will have difficulty managing everyday affairs, feeling inadequate to create changes in their surroundings, unaware of opportunities around them, and unable to control the external world situation.

The fifth dimension is purpose in life. An individual will have a sense of meaning in life when he or she positively has purpose, intentions, direction. Individuals who have high marks on a dimension of purpose in life will hold confidence in the purpose of life; To view past and present events as meaningful; And aim life towards purpose. The sixth dimension is personal growth. The individual needs to develop his potential to grow as a person who achieves optimal psychological function.

\subsubsection{Factors Affecting Psychological Well- Being}

Ryff and Singer (1996) [23] explain factors affecting psychological swings. The first factor is gender. According to Ryff and Singer (1996) data found that women of all ages rate themselves higher on positive relationships with others. Women tend to have higher value in the personal growth dimension. The second factor is the socioeconomic class. Generally social economic differences in education, income, and jobs are correlated to psychological wellbeing. The third factor is culture. Cultural differences guide to self-concept in relating to others. Cultural factors relate to a dimension of self-acceptance, self-reliance, and positive relationships with other individuals.

\subsection{Religiosity}

\subsubsection{Definition of Religiosity}

According to Huber (2012), religiosity refers to the depth of religious significance in one individual. Criteria that can be measured in religiosity on the basis of belief, personal religious practice, interest in religion, and relationships with religious communities. Holdcroft (2006) [24] claims that religious concepts are difficult to define because of uncertain and complex traits. The definition of the complex property in question is the difference in outlook. According to Glock and Stark, religiosity is a form of belief that has connotation in life by internalizing it into daily life (in Nasikhah \& Prihastuti, 2013) [25]. Allport and Ross (1967) [26] explain the religious concept to the application of religious knowledge with two intrinsic and extrinsic dimensions.

\subsubsection{Dimension of Religiosity}

Huber (2012) describes five dimensions of religiosity. The intellectual dimension explains the knowledge that the individual has about religion so that he can explain about its religion, the Lord, and its diversity. Spatial dimensions. This explains that religious individuals have confidence in the existence and essence of the Lord. Furthermore, this dimension also links human and divine relationships. The public practice dimension explains that as religious individuals participate in community activities in religious, ritualistic, and ceremonial activities. The dimension of private practice refers to private religious practices and activities. Religious experience is experience-oriented, relating experiences directly with god that have an emotional effect on personal individuals.

Glock and Stark (in Holdcroft, 2006) formulated five dimensions of the religiosity consisted of experiential, ritualistic, ideological, intellectual, and consequential. Experiential dimensions focused on personal faith and related experiences with the Lord. Ritualistic dimension related dimensions of individuals that involve themselves in an experience of worship in a community. Ideological dimension deals with individual beliefs with believable religion. Intellectual dimension relates to individual knowledge of the basic principles of faith and scripture according to their religion. Consequential dimensions are an individual commitment with a held religion.

\section{METHOD}

\subsection{Subject and Design}

The participants in this study are young adult women with an age span of 20 to 40 years. At this age there are hormonal changes and life-style changes that cause acne problems. The data collection process uses nonprobability sampling methods, with purposive sampling technique. There are 306 subjects in all research participants. 


\subsection{Instruments}

\subsubsection{Psychological Well-Being}

The study uses psychological-well being measurement and methods based on Ryff's theory (1989). Now, this device here measures roots, measures six dimensions of psychological swings. There are 31 of 24 positive items and 7 negative items. Responses is measured with a liquid scale. The likert scale has five choices of answers made up of TS (disagree), KS (disagree), AS (rather agree), S (agree), and SS (strongly agree). The reliability of every psychological well-being dimension can be seen at table 1 .

Table 1 Reliability Measure of Psychological Well-Being Dimension Cronbach's Alpha

$(\alpha)$

\begin{tabular}{lc}
\hline Self-Acceptance & .784 \\
Positive Relations with Others & .722 \\
& .622 \\
Autonomy & .773 \\
Environmental Mastery & .727 \\
Purpose in Life & .6 \\
Personal Growth & \\
\hline
\end{tabular}

\subsubsection{Religiosity}

The religiosity measurement used in Huber's theory (2012) is the centrality of religiosity scale (CRS). This measuring root measures five dimensions of religiosity consisting of 33 items. The reason for this measuring device is because the religiosity of Huber's theory is generalized for all beliefs. There are 30 positive items and 3 negative items in this measuring device consisting of 15 items that have been adapted to the language aspect and 18 new ones added (Purnomo \& Haryadi, 2017). Responses will be measured with a liquid scale. The likert scale has five answers of STS (strongly disagree), TS (disagree), S (agree), and SS (strongly agree). The resulting realiability of every religious dimension can be seen at table 2 .

Table 2 Reliability Measure of Religiosity

\begin{tabular}{lc}
\hline \multicolumn{1}{c}{ Dimensi } & Cronbach's Alpha $(\alpha)$ \\
\hline Intellectual & .775 \\
Ideology & .824 \\
Public Practice & .89 \\
Private Practice & .808 \\
Religious Experience & .855 \\
\hline
\end{tabular}

\section{RESULT}

\subsection{Normality Test}

Normality tests are performed on two research variables: religiosity and psychological diversity. The result obtained through the process of Kolmogorov-Smirnov was religious variable with $0.614>0.05$ and $\mathrm{Z}$ value $=0.758$. Psychological well-being variables comparison with 0864 $>0.05$ and $\mathrm{z}$ scores $=0.6$. Based on normality tests using Kolmogorov-Smirnov, data distribution is normal.

\subsection{Linearity Test}

Linearity test is conducted to determine the relationship between variable IV and variable DV is linear (straight line) significantly or not. The reference to linear data assessment is when significance (p) $>0.05$, then the data is stated as linear. Conversely, when data testing shows significant value $(\mathrm{p})<0.05$, the data is not linear. Based on the linearity test between religiosity and psychological well-being, a significance value of IV to DV was obtained, namely $(\mathrm{p})=0.194>0.005$.

\subsection{Regression Test}

Based on linear regression of religiosity to psychological well-being in early adult women who had acne problems. Linear regression test obtained that the value of $\mathrm{F}=$ $48.894, p=0.000<0.05$, ANOVA table which means that simultaneously religiosity has a significant role on psychological well-being. Apart from the results of the linear regression test, the results obtained were $R^{2}=0.139$ which explained that the contribution of religiosity to psychological well-being was $13.9 \%$ and the rest was influenced by other factors outside the study. The coefficients table shows the role of religiosity on psychological well-being through $t$ and $p$ values. In the coefficients table, there is a $t$ value of religiosity is 6.992 with $\mathrm{p}=0.000<0.05$, which means that religiosity has a significant positive role on psychological well-being. So it can be concluded that the higher the subject's religiosity, the higher the psychological well-being of the subject and vice versa.

The regression test results show that the intellectual dimension has a role of $11.1 \%$, with a significance level of $\mathrm{p}=0.000<0.05$, the ideological dimension has a role of $4.9 \%$, with a significance level of $p=0.000<0.05$, the public practice dimension has a role of $9.2 \%$, with a significance $\mathrm{p}=0.002<0.05$, the private practice dimension has a role of $2.7 \%$, with a significance level of $\mathrm{p}=0.004<0.05$, the religious experience dimension has a role of $13.4 \%$ with a significance level of $0.000<0.05$.

\section{DISCUSSION}

The result of the study stated that even religiosity played a role of $13.9 \%$ on psychological well-being. The result that the researchers found was that the religious experience dimension had the biggest role on psychological wellbeing, amounting to $13.4 \%$. Meanwhile, the private practice dimension has the smallest role on psychological well-being, which is $2.7 \%$ 
The results in this study are in line with the research of Hamidah and Gamal (2019), Mirehtu (2019), and Amawidyati and Utami (2015) [27] with the result that there is a positive correlation between psychological wellbeing and religiosity variables. This correlation is significant positive, which means that the higher the religiosity score, the higher the psychological well-being score. Amawidyati and Utami's research (2015) proved that religiosity has an effect of $25.5 \%$ on psychological well-being.

Each dimension of religiosity plays a role in psychological well-being. Ideological dimension contributed $7.9 \%$. In Linawati and Desiningrum's (2018) research, ideological dimension plays a role. Religiosity gave a role of $57.2 \%$ to psychological well-being of students of Muhammadiyah 7 Semarang Junior High School and $42.8 \%$ was determined by other factors.

The private practice dimension has a role value for psychological well-being with a percentage of $2.7 \%$, while the public practice dimension has a role with a percentage of 9.2\%. In the research of Lavrič and Flere (2008) [28] stated that religious practice is very useful for psychological well-being. This religious practice is shown as the presence of individuals in religious events. Research by Boppana and Gross (2019) [29] also states that the presence of individuals in places of worship is positively related to the psychological well-being of LGBT people who adhere to Christianity. Research by Maltby et al. (1999) [30] stated that the frequency of personal prayer is a dominant factor in the relationship between religiosity and psychological well-being. The frequency of personal prayer was also significantly positively associated with self-esteem and significantly negatively associated with depression and anxiety.

The dimension of religiosity that played the most role in psychological well-being of early adult women experiencing acne problems was the religious experience dimension with a percentage of $13.4 \%$. Mnuk and Marcinkowski (2012) [31] examined the relationship between spiritual experience and psychological well-being with indicators of positive affect and negative affect and satisfaction life. The results of the study stated that spiritual experience was positively related to psychological well-being indicators, namely positive affect and satisfaction life. The meaning of life and hope become a mediator between spiritual experience and life satisfaction. The role of the religious experience dimension on psychological well-being is also in line with the research results of Azalia et al. (2018) [32] in the recitation congregation. In this study stated that the most important aspects of religiosity were experience, worship, and morals with a value of $p=0.001<0.05$. When compared with the ideological dimension, it has a value of $p=0.264>0.05$ and the intellectual dimension has a value of $p=0.866>$ 0.05 .

Researcher provides suggestions for further research to correlated with other variables that can be associated with religiosity such as spiritual well being, subjective wellbeing, gratitude, self-esteem, resilience, quality of life, and self-confidence. Further research on religiosity and psychological well-being can also use criteria for other participant subjects.

\section{CONCLUSION}

This study aims to determine the role of religiosity on psychological well-being in early adult women who have acne problems. The magnitude of the role of religiosity on psychological well-being in early adult women who have acne problems was found to be $13.9 \%$. The dimension of religiosity that plays the most role in psychological wellbeing is the dimension of religious experience. This dimension accounts for $13.4 \%$. This shows that the hypothesis that there is a role for religiosity on psychological well-being in early adult women who experience acne problems is accepted. Individuals who have high religiosity scores have high psychological wellbeing, on the other hand, subjects who have low religiosity scores have low psychological well-being. The conclusion that can be drawn is that religiosity has a role to improve psychological well-being for the better.

\section{REFERENCES}

[1] Zaenglein, A. L. (2018). Acne Vulgaris. New England Journal of Medicine, 379(14), 1343-1352. https://doi.org/10.1056/NEJMcp1702493

[2] Kumampung, D. R. (2019, December 12). Jerawat jadi keluhan 2 juta prang Indonesia, apa solusinya? KOMPAS. https://lifestyle.kompas.com/read/2019/12/ 12/204658820/jerawat-jadi-keluhan-2-juta-orangindonesia-apa-solusinya?page $=$ all\#page 2

[3] Mutiah, D. (2020, August 23). Survei: $77 \%$ perempuan berjerawat di Indonesia jadi korban acne shaming. Liputan 6. https://www.liputan6.com/lifestyle/ read/4337072/survei-77-\%-perempuan-berjerawat-diindonesia-jadi-korban-acne-shaming

[4] Alajlan, A., Al Turki, Y. A., AlHazzani, Y., Alhowaish, N., AlEid, N., Alhozaimi, Z., Saleh, W. A., Yahya, A. B., Alkriadees, Y., \& Alsuwaidan, S. (2017). Prevalence, level of knowledge and lifestyle association with acne vulgaris among medical students. Journal of Dermatology \& Dermatologic Surgery, 21(2), 58-61. https://doi.org/10.1016/j.jdds.2017.01. 001

[5] Kaur, S., Verma, P., Sangwan, A., Dayal, S., \& Jain, V. K. (2016). Etiopathogenesis and therapeutic approach to adult onset acne. Indian Journal of Dermatology, 61(4), 403-407. https://dx.doi.org/10. 4103\%2F0019-5154.185703 
[6] Gao, Y., Wei, E. K., Arron, S. T., Linos, E., Margolis, D. J., \& Mansh, M. D. (2017). Acne, sexual orientation, and mental health among young adults in the United States: A population-based, cross-sectional study. Journal of the American Academy of Dermatology, 77(5), 971-973. https://doi.org/10.1016/ j.jaad.2017.06.004

[7] Sarkar, S., Patra, P., Mridha, K., Ghosh, S. K., Mukhopadhyay, A., \& Thakurta, R. G. (2016). Personality disorders and its association with anxiety and depression among patients of severe acne: A crosssectional study from Eastern India. Indian Journal of Psychiatry, 58(4), 378-382. https://dx.doi.org/10. $4103 \% 2 F 0019-5545.196720$

[8] Bassi, M., Delle Fave, A., Cetin, I., Melchiorri, E., Pozzo, M., Vescovelli, F., \& Ruini, C. (2017). Psychological well-being and depression from pregnancy to postpartum among primiparous and multiparous women. Journal of Reproductive and Infant Psychology, 35(2), 183-195. https://doi.org/10. $1080 / 02646838.2017 .1290222$

[9] Pradhan, S., \& Xiong L. (2017). Psychological disorder among acne patients. Journal of Kathmandu Medical College, 6(1), 38-39. https://doi.org/10.3126/ jkmc.v6i1.18586

[10] Traube, M. (2017, Desember 10). The toll of adult acne: The psychological impact of adult acne can be highly significant. Psychology Today. https://www. psychologytoday.com/intl/blog/healthy-mind-healthyskin/201712/the-toll-adult-acne

[11] World Health Organization. (2018). WHO World Mental Health Day 2018 - Young people and mental health in a changing world. https://www.who.int/ newsroom/events/detail/2018/10/10/defaultcalendar/world-mental-health-day-2018

[12] Mehmood, T., \& Shaukat, M. (2014). Life Satisfaction and Psychological Well-being among Young Adult Female University Students. International Journal of Liberal Arts and Social Science, 2(5), 143153. https://www.ijlass.org/data/frontImages/gallery/ Vol._2_No._5/15.pdf

[13] Zimmer, Z., Jagger, C., Chiu, C.-T., Ofstedal, M. B., Rojo, F., \& Saito, Y. (2016). Spirituality, religiosity, aging and health in global perspective: A review. SSM Population Health, 2, 373- 381. https://doi.org/10.1016/ j.ssmph.2016.04.009

[14] Huber, S. (2012). The centrality of religion scale (CRS). Religions ,3(3), 710-724 https://doi.org/10. 3390/rel3030710
[15] Dew, R. E., Daniel, S. S., Armstrong, T. D., Goldston, D. B., McCall, W. V., Kuchibhatla, M., Trippett, M. F., \& Koenig, H. G. (2010). A prospective study of religion/spirituality and depressive symptoms among adolescent psychiatric patients. Journal of Affective Disorders, 120(1-3), 149-157. https://doi.org/ 10.1016/j.jad.2009.04.029

[16] Kaliampos, A., \& Roussi, P. (2015). Religious beliefs, coping, and psychological well-being among greek cancer patients. Journal of Health Psychology, 22(6), 754-764. https://doi.org/10. $1177 \% 2 \mathrm{~F} 1359105315614995$

[17] Hamidah, T., \& Gamal, H. (2019). Hubungan religiositas dengan psychological well-being pada anggota satpamwal denma mabes TNI. Jurnal IKRAITH-Humaniora, 3(2), 139-146. http://journals. upi-yai.ac.id/index.php/ikraith-humaniora/article/ download $/ 451 / 333$

[18] Linawati, R. A., \& Desiningrum, D. R. (2018). Hubungan antara religiositas dengan psychological well-being pada siswa SMP Muhammadiyah 7 Semarang. Jurnal Empati, 7(3), 105-109. https:// ejournal3.undip.ac.id/index.php/empati/article/view/197 38

[19] Davis III, R. F., \& Kiang, L. (2015). Religious Identity, Religious Participation, and Psychological Well-Being in Asian American Adolescents. Journal of Youth and Adolescence, 45(3), 532-546. https:// doi.org/10.1007/s10964-015-0350-9

[20] Weber, S. R., \& Pargament, K. I. (2014). The role of religion and spirituality in mental health. Current Opinion in Psychiatry, 27(5), 358-363. https://doi. org/10.1097/yco.0000000000000080

[21] Ryff, C. D. (1989). Happiness is everything, or is it? explorations on the meaning of psychological wellbeing. Journal of Personality and Social Psychology, 57(6), 1069-1081. https://doi.org/10.1037/0022-3514. 57.6.1069

[22] Wells, I. E. (2010). Psychological well-being. Nova Science Publishers.

[23] Ryff, C. D., \& Singer, B. (1996). Psychological well-being: Meaning, Measurement, and implications for psychotherapy research. Psychotherapy and Psychosomatics, 65(1), 14-23. https://doi.org/10.1159/ 000289026

[24] Holdcroft, B. B. (2006)._What is religiosity. Catholic Education: A Journal of Inquiry and Practice, 
10(1), 89-103. http://dx.doi.org/10.15365/joce. 1001082013

[25] Nasikhah, D, \& Prihastuti (2013) Hubungan antara tingkat religiusitas dengan perilaku kenakalan remaja pada masa remaja awal. Jurnal Psikologi Pendidikan dan Perkembangan, 2(2), 69-72. http://journal.unair. ac.id/download-fullpapers-jppp3aed4ecac02full.pdf

[26] Allport, G. W., \& Ross, J. M. (1967). Personal religious orientation and prejudice. Journal of Personality and Social Psychology, 5(4), 432-443. http://dx.doi.org/10.1037/h0021212

[27] Amawidyati, S. A. G., \& Utami, M. S. (2015). Religiusitas dan psychological well-being pada korban gempa. Jurnal Psikologi, 34(2), 164-176. https:// jurnal.ugm.ac.id/jpsi/article/view/7095

[28] Lavrič, M., \& Flere, S. (2008). The role of culture in the relationship between religiosity and psychological well-being. Journal of Religion and Health, 47(2), 164-175. https://link.springer.com/ article/10.1007/s10943-008-9168-z

[29] Boppana, S., \& Gross, A. M. (2019). The impact of religiosity on the psychological well-being of LGBT christians. Journal of Gay \& Lesbian Mental Health, 23(4), 1-15.

[30] Maltby, J., Lewis, C. A., Day, L. (1999). Religious orientation and psychological well-being: The role of the frequency of personal prayer. British Journal of Health Psychology,4(4), 363-378. https://doi.org/10. 1348/135910799168704

[31] Mnuk, M., \& Marcinkowski, J. (2012). Do existential variables mediate between religious-spiritual facets of functionality and psychological wellbeing. Journal of Religion and Health, 53(1). https:// doi.org/10.1007/s10943-012-9597-6

[32] Azalia, L., Muna., L. N., \& Rusdi, A. (2018). Kesejahteraan psikologis pada jemaah pengajian ditinjau dari religiusitas dan hubbud dunya. Jurnal Psikologi Islami, 4(1), 35-44. http://jurnal.radenfatah. ac.id/index.php/psikis/article/view/2159 